УДК 378.091.68:004.738.5

Биков Валерій Юхимович, доктор технічних наук, професор, дійсний член НАПН України, директор Інституту інформаційних технологій і засобів навчання НАПН України, м. Київ, valbykov@gmail.com

\title{
ІКТ-АУТСОРСІНГ І НОВІ ФУНКЦІЇ ІКТ-ПІДРОЗДІЛІВ НАВЧАЛЬНИХ ЗАКЛАДІВ І НАУКОВИХ УСТАНОВ
}

\begin{abstract}
Анотація
Надано широкий за напрямками і глибокий за дослідженнями аналіз сучасного етапу інформатизації суспільства й освіти. 3 позицій системного підходу розглянуто інноваційний причинно-наслідковий ланцюг, що висвітлює і деталізує загальну проблему — невідповідність організаційно-функціональної структури IT-підрозділів освітніх закладів і наукових установ об' єктивним умовам сучасного стану розвитку засобів і технологій інформаційного суспільства. У зв'язку 3 актуальністю застосування на сучасному етапі інформатизації системи освіти механізму аутсорсингу для забезпечення функціонування і розвитку ІКТ-систем освітніх організаційних структур, розглянуто деякі теоретико-практичні аспекти цього поняття і явища. Окреслено функції ІКТ-підрозділів, що підтримують і розвивають IКТ-системи на базі адаптивних інформаційно-комунікаційних мереж, тобто тих, які у своїй роботі спираються на хмарну (корпоративну або загальнодоступну) ІКТінфраструктуру.
\end{abstract}

Ключові слова: інформатизація освіти, аутсорсинг, освітні організаційні структури, хмарні технології.

Актуальність і постановка проблеми. Глобальна економіка, побудована на знаннях, нині багато в чому стала реальністю. Експоненційне зростання знань i пов'язані з цим радикальні технологічні зміни по іншому ставлять традиційні проблеми здобування знань, опанування знаннями в професійному середовищі й освіті наступних поколінь. Принциповим компонентом здійснюваних змін $\epsilon$ інформаційно-комунікаційні технології (ІКТ). Освіта нині виходить за традиційні рамки - змістово-предметні, організаційні, географічні, що встановлювались 
протягом століть. Це $\epsilon$ імперативом прогресу i конкурентоспроможності. Освіта впродовж життя стає критично важливим елементом сталого розвитку суспільства [1, c. 105$]$.

Стрімкий розвиток комп’ютерних засобів та IКТ, зокрема цифрових й оптиковолоконних, їх широке впровадження в усі сфери суспільного життя прискорили інтеграційні й комунікаційні процеси, забезпечили нові більш продуктивні можливості опрацювання електронних даних. Ці технології стрімко просувають нас по шляху до інформаційного суспільства, до майбутнього, але насправді вже досить близького суспільства знань. Нині „визначальним стали інтелект і освіта, які перетворюють сучасне суспільство на суспільство знань” [2, с. 10].

Отже ІКТ, що блискавично і невпинно розвиваються, каталізують усі без винятку процеси науково-технічного i суспільного розвитку країни, разюче впливаючи на характер розвитку педагогічних систем і системи освіти (СО) в цілому. Проте, для забезпечення інтеграції системи освіти України до Європейського i світового освітнього простору, не вдасться обмежитися лише організаційними заходами (як здається декому), слід зробити рішучі кроки в напрямі модернізації цільових і змістово-технологічних аспектів освіти, що базуються на широкому застосуванні IKT.

Виклад основного матеріалу. Саме інформатизація суспільства передбачає випереджальну інформатизацію галузі науки й освіти, де в основному формується когнітивний, кадровий i науково-технічний фундамент самої інформатизації як процесу i соціально-економічного явища, закладаються майбутнє досягнень i розвитку суспільства в цілому.

Інформатизація СО — це сукупність взаємопов’ язаних організаційно-правових, соціально-економічних, навчально-методичних, науково-технічних, виробничих та управлінських процесів, спрямованих на задоволення інформаційних, обчислювальних i телекомунікаційних потреб (інших потреб, що пов’язані 3 упровадженням методів і засобів IKT) учасників навчально-виховного процесу, а також тих, хто цим процесом управляє і його забезпечує (у тому числі здійснює його науково-методичний супровід і розвиток) [3, с. 140]. Тобто інформатизація СО передбачає реалізацію комплексу системних заходів, спрямованих на забезпечення 
використання суб'єктами СО вірогідного, вичерпного і своєчасного знання у разі здійснення ними всіх видів діяльності.

Інформатизація $\mathrm{CO} є$ наскрізним, всеохоплюючим напрямом інноваційного розвитку освітньої системи, ресурси якого ще належно не задіяні. Формування в Україні інформаційного суспільства зумовлює як прямий його вплив на модернізацію $\mathrm{CO}$, так і опосередкований, пов’ язаний із виникненням нового способу життя, зміною його якості. Швидкий розвиток IКТ, поширення нових методичних систем навчання створюють умови для необмеженого (повного, швидкого, точного, будь-коли і будьде, з мінімальними зусиллями та ін.) доступу всіх суб'єктів навчання до електронних освітніх ресурсів (ЕОР). Цей процес набуває все більших масштабів й інтенсивності, а його результати переконують, що для IКТ не існує альтернативи в сучасному світі.

Розглянемо деякі аспекти сучасного етапу інформатизації суспільства і освіти, що є суттєвими в контексті теми цієї статті.

На початку зазначимо, що до складу СО входять різні типи освітніх організаційних структур (ООС), що здійснюють і забезпечують освітню діяльність дошкільні, загальноосвітні, професійно-технічні, вищі навчальні заклади, наукові і методичні установи, позашкільні навчально-виховні заклади, навчальні заклади системи післядипломної педагогічної освіти, підприємства, органи управління освітою і наукою, молоддю та спортом на всіх організаційних рівнях СО. Проте існують певні питання, зокрема ті, що відносяться до організаційно-функціональних завдань ІТ-підрозділів ООС і відповідного професійне зростання їх персоналу, що $\epsilon$ загальними, витікають із загальних проблем, цілей та обраних напрямів сучасного етапу інформатизації СО, і тому не залежать від конкретного типу ООС, що входять до складу СО. Тому у подальшому викладі, коли будемо говорити про проблеми i функції ІТ-підрозділів ООС, про професійне зростання їх персоналу на сучасному етапі інформатизації СО, припустимо, що все наведене стосується не тільки, наприклад, навчальних закладів, а всіх зазначених вище типів ООС.

Введемо деякі означення, що необхідні для однозначного розуміння подальшого викладу.

Бізнес-процееси (англ. business — справа, заняття, бізнес) - послідовна зміна станів функціонування і розвитку ООС, зв'язок між якими визначається змістом 
виробничих функцій ООС (основних функцій — освітніх, наукових, виробничих і не основних — допоміжних).

IKT-процеси - послідовна зміна станів функціонування і розвитку ІКТсистеми, зв'язок між якими визначається змістом інформаційно-ресурсних, інформаційно-комунікаційних та інформаційно-процесуальних функцій (IКTфункцій) підтримання бізнес-процесів.

Отже, загальний склад процесів, що реалізуються ООС, утворюють сукупність бізнес-прочесів та IKT-процесів.

Корпоративна IКТ-система, або просто, IКТ-система - складова ООС, що забезпечує ефективну реалізацію корпоративних ІКТ-процесів, в якій збирання та опрацювання даних здійснюється автоматизовано за допомогою відповідних засобів комп'ютерної техніки та IКТ. Засоби і технології корпоративної ІКТ-системи утворюють в ООС гнучке й адаптивне інтегроване організаційно-технологічне та інформаційно-обчислювальне середовище, що розвивається і активно та визначально впливає на формування в ООС найбільш сприятливих (інформаційно-комфортних) умов для ефективного здійснення її функцій.

Корпоративний бізнес-підрозділ, або просто, бізнес-підрозділ - організаційнофункціональна складова ООС, що включає суб'єктів реалізації бізнес-процесів, діяльність яких деяким чином організуються для ефективного досягнення цілей функціонування і розвитку ООС.

Корпоративний IKT-niдрозділ, або просто, IKT-nідрозділ - складова ІКТсистеми, організаційно-функціональна складова ООС, що включає суб'єктів реалізації ІКТ-процесів, діяльність яких деяким чином організуються для ефективного досягнення цілей функціонування і розвитку ІКТ-системи.

Отже, загальний склад організаційно-функціональної будови ООС, утворюють сукупність бізнес-підрозділів і IKT-підрозділу.

Функиія IKT-підрозділу (ІКТ-групи, ІКТ-команди, ІКТ-персоналу) - визначає цільове призначення ІКТ-підрозділу (ІКТ-групи, ІКТ-команди, ІКТ-персоналу), прояв результатів його діяльності в користувальному середовищі ООС, змістову частину завдань, що розв'язує підрозділ, 3 підтримання діяльності бізнес-підрозділів і забезпечення функціонування, доцільного i збалансованого розвитку засобів i технологій ІКТ-систем. 
Нормативно-інструктивне забезпечення ІКТ-системи - складова ІКТсистеми, що визначає порядок реалізації ІКТ-процесів, який задається сукупністю унормованих і формалізованих правил (включаючи вимоги, дозволи і обмеження) функціонування і розвитку ІКТ-системи.

IKT-засіб діяльності (навчання), або просто, IКТ-засіб - різновид засобу діяльності (навчання), функціонування якого базується, а застосування орієнтоване на використання методів і засобів інформатики.

Аутсорсинг (англ. outsourcing) — cервіс, що необхідний певній системі для реалізації ii основної функції, який пропонує i реалізує інша система, зовнішня відносно даної.

Закрите комп'ютерно орієнтоване навчальне середовище - ІКТ-навчальне середовище педагогічних систем, у якому окремі дидактичні функції передбачають педагогічно доцільне використання комп'ютерних і комп'ютерно орієнтованих засобів навчання, ЕОР, а також засобів і сервісів локальних інформаційнокомунікаційних мереж (IКМ) навчального закладу.

Закрите комп'ютерно інтегроване навчальне середовище - ІКТ-навчальне середовище педагогічних систем, у якому окремі дидактичні функції, а також принципово деякі важливі функції управління навчальним процесом, передбачають педагогічно доцільне координоване й інтегроване використання комп'ютерних i комп'ютерно орієнтованих засобів навчання, ЕОР, а також засобів i сервісів локальних IКМ навчального закладу.

Відкрите комп'ютерно орієнтоване навчальне середовище - ІКТ-навчальне середовище педагогічних систем, у якому окремі дидактичні функції передбачають педагогічно доцільне використання комп’ютерних і комп’ютерно орієнтованих засобів навчання й ЕОР, що входять до складу ІКТ-системи навчального закладу, а також засобів, ресурсів і сервісів відкритих IКМ (Інтернет).

Відкрите комп'ютерно інтегроване навчальне середовище - ІКТ-навчальне середовище педагогічних систем, у якому переважна більшість дидактичних функцій, а також принципово, деякі важливі функції управління навчальним процесом, передбачають педагогічно доцільне координоване й інтегроване використання комп’ютерних і комп’ютерно орієнтованих засобів навчання й ЕОР, що входять до 
складу ІКТ-системи навчального закладу, а також засобів, ресурсів і сервісів відкритих IКМ (Інтернет).

Персоніфіковане комп'ютерно інтегроване навчальне середовище - відкрите комп'ютерно інтегроване навчальне середовище педагогічних систем, у якому забезпечується налаштування ІКТ-інфраструктури (у тому числі віртуальної) на індивідуальні інформаційно-комунікаційні, інформаційно-ресурсні й операційнопроцесуальні потреби учасників навчального процесу.

Відразу зауважимо, що інформатизація СО не повинна проводитися „,як річ у собі”, як „данина моді”. Вона, передусім, має бути спрямованою на забезпечення конкурентоспроможності ООС на вітчизняному i міжнародному ринках освітніх послуг, а їхніх випускників - на відкритому ринку праці i зайнятості. Тому інформатизація СО має бути пов’язаною з кінцевими результатами діяльності ООС, забезпечити ефективність впливу іiі засобів, технологій і заходів на основні освітні результати.

Результативність інформатизації СО багато в чому залежить не тільки від того, які і скільки засобів та IКТ застосовуються в ООС для підтримання навчальної, наукової й управлінської діяльності, якої ці засоби і технології якості, наскільки досконало ними володіють учні, учителі, науково-методичні працівники та організатори освітнього процесу, наскільки активно і педагогічно виважено вони застосовуються. Ці чинники, безумовно, є дуже важливими для забезпечення високої ефективності процесу інформатизації СО та ії складових.

Проте, результативність інформатизації СО визначально залежить і від того: як побудовані ІКТ-системи, що інформаційно-процесуально забезпечують всі види діяльності ООС, складають комп'ютерно-технологічний фундамент середовища діяльності ООС, зокрема, навчального середовища; як побудований, які функції виконує, за якими правилами працює ІКТ-підрозділ ООС, його працівники, що складають кадрове ядро автоматизованої ІКТ-системи; як автоматизовані функції цих систем поділяються між ІКТ-підрозділом та іншими підрозділами ООС (за введеним вище означенням - бізнес-підрозділи ООС). Розкриття цих питань, надання відповідей на них складає зміст подальшого викладу.

Для цього, спочатку, розглянемо інноваційний причинно-наслідковий ланцюг, що висвітлює i деталізує загальну проблему - невідповідність організаційно- 
функціональної структури IT-підрозділів ООС об’єктивним умовам сучасного стану розвитку засобів і технологій інформаційного суспільства: $\rightarrow$ об’єктивних змін, що відбулися останнім часом в ІКТ-середовищі, яке підтримує інформаційний простір сучасного суспільства, у компонентному складі і структурі, функціях ІКТ-платформи цього простору; $\rightarrow$ як це має відобразитися у будові IКТ-середовища діяльності ООС i СО в цілому; $\rightarrow$ які організаційно-функціональні ІКТ-проблеми (окрім змістових інформаційно-ресурсних і поточних, що безпосередньо не зв'язані із сучасним етапом загальносистемного інноваційного розвитку ІКТ-систем) виникли і рельєфно проявилися в ООС; $\rightarrow$ як у зв’язку з цим мають бути змінені функції ІКТ-підрозділу, розподіл відповідних функцій між ІКТ-підрозділом і бізнес-підрозділами ООС; $\rightarrow$ які нові освітні завдання виникають у підготовці кадрового корпусу фахівців для ІКТсфери.

Послідовно розглянемо п’ять складових цього ланцюга більш докладно.

По-перше, те, що стосується сучасного стану і тенденцій розвитку ІКТплатформи інформаційного простору сучасного суспільства.

В останні роки подальшого динамічного розвитку набувають засоби i технології IKM, зокрема Інтернет, що утворюють комп'ютерно-технологічну платформу навчального середовища сучасної освіти, передусім відкритої. На цій основі здійснюється предметно-технологічна організація інформаційного освітнього простору, упорядковуються процеси накопичення і зберігання різних предметних колекцій ЕОР, забезпечується рівний доступ до них тих, хто навчається, суттєво покращується ІКТ-підтримка процесів навчання, проведення наукових досліджень й управління освітою. Це сприяє підвищенню якості освітніх послуг, інтеграції системи освіти України у світовий освітній простір.

На основі здобутків науково-технічного прогресу в ІКТ-сфері провідні функціонально-технологічні характеристики ІКМ еволюційно змінюються, поступово поліпшуючи свої користувальні інформаційно-комунікаційні й операційнопроцесуальні властивості: від виключного інформаційно-транспортних - на першому, початковому етапі, до інформаційно-контентних (змістових) — на другому, інформаційно-сервісних - на третьому, i, нарешті, інформаційно-адаптивних — на сучасному четвертому. 
Функції і відповідна будова адаптивних IКМ концентровано відображають концепцію опрацювання електронних даних на основі інформаційних технологій хмарних обчислень (ХО). За цією концепцією завдяки спеціальному інтерфейсу користувача, що підтримується системними програмними засобами мережного налаштування, в адаптивних IКМ формуються мережні віртуальні ІКТ-об'єкти. Такі об’єкти - мережні віртуальні майданчики як ситуаційна складова логічної мережної інфраструктури ІКМ з тимчасовою відкритою гнучкою архітектурою, що за своєю будовою i часом існування відповідає персоніфікованим потребам користувача (індивідуальним і груповим), а їхнє формування і використання підтримується ХОтехнологіями.

Відповідно до цього підходу адекватно змінюються і ІКТ-засоби. На світовому ринку ІКТ-засобів взаємозв’язку „користувач - IКМ” уже нині набули помітного поширення ІКТ-засоби нового покоління, що своїми користувальними властивостях відображають особливості функцій, будови і параметрів нової мережної хмарної ІКТінфраструктури (iPAD, imPad, iPad-Hibrid, Reder, iPhone, SmartPhone, iPod, мультимедійні дошки з Інтернет доступом і т. ін.).

Поряд із вимогами щодо процесуальних властивостей таких засобів (швидкодія, обсяг пам'яті та ін.) на перший план вийшла їх мобільність. 3’явилися мобільні Інтернет пристрої (Mobil Internet Device), для яких характерні: малі масогабаритні параметри i електроспоживання та довготривале автономне енергозабезпечення; планшетна (кишенькова) високоергономічна конструкція; швидкий, зручний i безпечний мультисервісний сенсорний екран 3 гіроскопічною функцією і високою розрізняльною здатністю; повний спектр засобів і протоколів під'єднання до інших комп’ютерних, аудіо- і відеозасобів, засобів друкування, ІКМ (Інтернет) i мобільних коміркових мереж; гнучке i систематично оновлюване мережними засобами програмне забезпечення. Попри це залишається можливість використання в хмарній ІКТ-інфраструктурі традиційних комп’ютерних ІКТ-засобів, таких як десктопи, ноутбуки і нетбуки та комп’ютерні мережні комплекси на їх основі.

Аналіз передового зарубіжного досвіду свідчить, за зазначеним підходом розвиваються ІКТ-засоби й ІКТ-інфраструктура в державному і приватному секторах, освіті та науці провідних країн світу (США, Сполучене Королівство, Японія), 
реалізуються відповідні проекти і програмами, що охоплюють практично всі сфери ІКТ-застосувань (країни Євросоюзу, Канада, Росія).

Для забезпечення соціально-економічної ефективності i конкурентоспроможності України, її успішної європейської і світової інтеграції згаданий підхід слід використовувати в процесі інформатизації всіх без винятку підсистем українського суспільства, передусім освіти, де ідеї і технології ХО мають стати предметом пріоритетного вивчення, засобами навчання, досліджень та управління освітою на всіх їі організаційних рівнях.

Масштаби виробництва і використання ІКТ-засобів, всеосяжна інформатизація суспільства зумовили помітний розвиток ІКТ-індустрії, у складі якою стрімкими темпами розвиваються фірми і компанії, що спеціалізуються на аутсорсингу 3 надання різним користувачам широкого спектру IКТ-послуг (компанії-аутсорсери).

Зокрема, на умовах аутсорсингу деякі фірми і компанії ІКТ-бізнесу здійснюють підтримку технологій хмарної інфраструктури і надання користувачам відповідних послуг. Ці компанії-аутсорсери у своїй діяльності спираються на розгорнуту i розгалужену світову мережу центрів даних (дата-центрів) 3 надвеликими потужностями процесорних, комунікаційних та зберігаючих кластерів. Водночас загальним для користувачів хмарної інфраструктури є впевненість у тому, що ІКТпотужності і сервіси адаптивних ІКМ у змозі задовольнити різноманітні потреби в опрацюванні даних.

У зв’язку з актуальністю застосування на сучасному етапі інформатизації СО механізму аутсорсинга для забезпечення функціонування і розвитку ІКТ-систем ООС, розглянемо деякі теоретико-практичні аспекти цього поняття і явища.

Оскільки за наведеним вище означенням аутсорсинг як сервіс визначається через основну функцію (далі, просто функція), з позицій задачного підходу зробимо деякі зауваження щодо розуміння категорій функції i сервісу, що виконують i надають ті чи інші системи. Визначимо, що зв'язує ці поняття, що є спільним між ними і що їх відрізняє.

Розглянемо деяку систему $S_{i}$, що виділена 3 оточуючого цю систему середовища $E_{i}$ за ознакою приналежності $S_{i}$ до реалізації певних цілей середовища $E_{i}$, тобто, $S_{i} \in E_{i}$. Ціль, яка задана для $S_{i}$, спрямовує діяльність $S_{i}$ щодо досягнення іi бажаного стану, майбутнього результату їі функціонування. Функція системи $S_{i}$ 
підпорядкована цій цілі, визначає іiї призначення в $E_{i}$, зовнішній прояв властивостей $S_{i}$ в $E_{i}$. Кажуть, що $S_{i}$ виконує в $E_{i}$ ті чи інші функції. Тому опис функціонування системи в термінах функцій відображає цільове призначення $S_{i}$, характеризує зовнішній прояв іiі функціонування в $E_{i}$, а саме функціонування $S_{i}$ виявляється відносно інших систем, що існують і функціонують в $E_{i}$ [3].

Функції визначаються через вивчення потреб ринку (послуг, товарів, капіталів, праці і т. ін.). Для практичного відтворення функції у тому чи іншому середовищі діяльності створюються відповідні системи, що реалізують (за рахунок створення організаційної і забезпечувальних підсистем) певні функції і пропонують на ринках кінцеві продукти свого функціонування - товари і послуги. Саме це відображає перетворення функції в її продуктивну модель - сервіс.

Що стосується категорії сервісу, то він відрізняється від функції тим, що включає всі види забезпечення (кадрове, фінансове, організаційне, матеріальнотехнічне, енергетичне), що необхідні для реалізації функції. Системи, що надають сервіс, реалізують (існують для реалізації) ті чи інші сервісні функції.

За задачним підходом сервісна функція — це формувальна частина практичної задачі з надання тої чи іншої послуги, формувальна частина моделі системи, що надає послуги (обслуговуюча, сервісна система). Сервісна функція описує зміст послуги (наприклад, як у рекламному проспекті) і не передбачає реалізацію різних можливих способів (шляхів) іï продукування і надання.

У свою чергу, сервіс передбачає надання за бажанням (зверненням та ін.) користувача послуги, що відповідає сервісній функції, яку здійснює фірма-провайдер (оператор, аутсорсер) послуги у процесі свого функціонування. Тобто сервіс включає як формувальну, так i реалізуючу частину моделі функціонування (діяльності) системи.

Зазначимо, що для сервісних компаній, надання тих чи інших послуг $є$ їх безпосереднім призначенням, тобто відповідає їх функції. Тому формулювання (визначення) функцій i сутність сервісів таких компаній змістово переважно збігаються.

Проте, правильне визначення функції сервісної компанії в оточуючому ऑii середовищі ще не означає надання нею якісних послуг. Тому дуже важливим є те, як побудовані забезпечувальні підсистеми сервісних компаній, що здійснюють 
допоміжні (на відміну від основних) функції, оскільки реалізація необхідної для ринку (користувачів, покупців послуг, учасників ринку) функції з точки зору споживача послуги може бути більш або менш привабливою (комфортною) за різними ознаками, наприклад, більш зручною, менш коштовною, в цілому - більш або менш якісною.

3 позицій системного підходу надамо формальний опис доцільності застосування аутсорсингу.

Нехай системи $S_{1}$ - дана (досліджувана) система, а $S_{2}$ - система аутсорсингу, що є забезпечувальною підсистемою для $S_{l}$.

До послуг аутсорсингу доцільно звертатися в тому разі, коли функція $F_{1}$, що реалізує (надає, пропонує на ринку) $S_{1}$, за змістом дуже відрізняється (є не типовою) від (для) основної функції $F_{2}$, що реалізує $S_{2}$, і для реалізації $F_{2}$ в межах $S_{1}$ слід здійснити суттєві перебудови, які потребують значного часу і додатково вимагають різних ресурсів, яких немає в наявності (на планову перспективу), наприклад, спеціальних виробничих приміщень, обладнання та устаткування, спеціально підготовленого персоналу, значного часу на здійснення заходів з перебудови $S_{l}$ та ін.

У тому разі, коли функції $F_{1}$ і $F_{2}$ змістово наближені, тобто $F_{2}$ не є абсолютно нетиповою для $S_{1}$, коли складність і трудомісткість реалізації $F_{2}$ не є дуже великими для $S_{1}$, або коли $S_{1}$,,зацікавлена" у підтриманні певного обсягу робіт з реалізації $F_{2}$ (наприклад, для здійснення професійних контактів і взаємодії з $S_{2}$, нагляду і контролю за якістю реалізації $F_{2} 3$ боку $S_{2}$, аналізу варіантів розвитку $S_{1}$ та ін.) доцільно в $S_{1}$ застосовувати комбіновані системи (комбінований підхід) реалізації $F_{2}$, коли певна (типово менша) $F_{2}-F_{2}{ }^{\prime}$ реалізується в межах $S_{1}$, а інша частина $F_{2}-F_{2}{ }^{\prime \prime}-$ за рахунок залучення аутворсингу $S_{2}, F_{2}=F_{2}{ }^{\prime \prime} \vee F_{2}{ }^{\prime \prime}$. Конкретне співвідношення між $F_{2}{ }^{\prime \prime} V F_{2}{ }^{\prime \prime}$ визначається для кожної конкретної функції $F_{l}$.

Приклади доцільного використання повного або комбінованого аутсорсингу: ремонтно-будівельні роботи й енергопостачання (капітальні ремонти і будівництво, роботи з поточної перевірки контрольно-вимірювальних приладів - виключно аутсорсинг, поточні ремонти і невеликі за обсягом і складністю роботи з внутрішньої перебудови - комбінований підхід); видавнича діяльність (значні за обсягом видання і великі наклади - виключно аутсорсинг, в іншому разі — комбінований підхід); консалтинг з юридичних послуг, фінансовий аудит, брокерські послуги 
(реалізують компанії, що здійснюють посередницькі функції, надають послуги посередництва) - виключно аутсорсинг; IKT-послуги (створення нових і докорінна модернізація існуючих ІКТ-систем, поточні ремонти складних засобів обчислювальної техніки, постачання нових й оновлених версій загального i спеціального програмного забезпечення, хостинг, провайдери Інтернет, провайдери загальнодержавних і міжнародних локальних і мережних ІКТ-сервісів (провайдери загальнодоступних хмарних послуг), розв'язування надскладних для $S_{l}$ обчислювальних задач — виключно аутсорсинг, усе інше - комбінований підхід.

Використання гнучкого підходу до застосування аутсорсингу дає змогу оптимізувати (за обраними критеріями) для $S_{1}$ співвідношення ,якість-вартість”

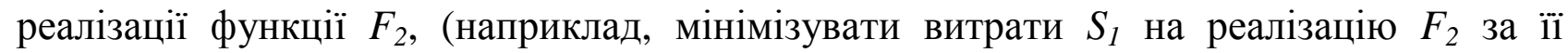
задовільної якості - якості, що задовольняє вимогам $S_{l}$ ).

По-друге, те, що стосується будови ІКТ-середовища діяльності ООС і CO в цілому.

Наведена вище еволюція ІКМ, розвиток їх функціонально-технологічних характеристик, необхідність їх врахування під час формування і використання сучасного ІКТ-середовища діяльності ООС зумовили відповідну еволюцію типів ІКТсередовищ діяльності ООС, що базуються на певних типах IКМ, використовують їх властивості, забезпечуючи для користувачів розширюваний спектр ІКТ-функцій.

Можливі масштаби і глибина ІКТ-підтримки навчального середовища залежить від типу ІКМ, функціонально-технологічні властивості яких у ньому повною мірою використовуються. Ці масштаби і глибина зростають на кожному етапі типології еволюційного розвитку IКМ, відповідно поглиблюючи типологію розвитку навчальних середовищ: на базі зазначених вище п’яти типів IКМ можуть бути побудовані і використовуватися у навчальному процесі чотири типи навчальних середовищ, означення яких наведені на початку цієї роботи. Так, на базі локальних IКМ ООС можуть бути побудовані і використовуватися в навчальному процесі лише два типи закритих навчальних середовищ: закрите комп’ютерно орієнтоване навчальне середовище і закрите комп'ютерно інтегроване навчальне середовище. На базі чотирьох відкритих IКМ (Інтернет): інформаційно-транспортних, інформаційноконтентних, інформаційно-сервісних та інформаційно-адаптивних - три типи відкритих навчальних середовищ: відкрите комп'ютерно орієнтоване навчальне 
середовище, відкрите комп’ютерно інтегроване навчальне середовище i персоніфіковане комп'ютерно інтегроване навчальне середовище.

Зазначимо, що незалежно від типу навчального середовища, що входить до складу певної педагогічної системи, у кожному з них може використовуватися весь спектр сучасних стаціонарних ІКТ-засобів навчання, а також усі види мобільних Інтернет-пристроїв.

По-третє, серед організаційно-функціональних ІКТ-проблем, що виникли і рельєфно проявилися в ООС, виділимо такі:

• деякі якісні показники ІКТ-підтримки бізнес-процесів ООС не задовольняють у повному обсязі цілі, поставлені перед ІКТ-системою керівництвом ООС, що, передусім, стосується вимог до гнучкості, зручності, швидкості та надійності надання ІКТ-сервісів за відповідними запитами користувачів;

- способи досягнення цілей ІКТ-системи (реалізація ІКТ-процесів) не досконалі i тому є не достатньо ефективними. Це проявляється як у технологічній будові програмно-апаратних засобів ІКТ-системи, оскільки під час реалізації ІКТ-процесів не застосовуються у повному обсязі останні досягнення в ІКТ-сфері, так і в організаційному забезпеченні реалізації ІКТ-процесів, зокрема, в організаційнофункціональній будові ІКТ-підрозділу - організаційно-суб'єктній частині ІКТсистеми, через невідповідність функцій, що виконує ІКТ-підрозділ, як сучасним завданням ІКТ-систем, умовам організації зовнішнього ІКТ-середовища, так i доцільному розподілу функцій між ІКТ-підрозділом і бізнес-підрозділами ООС, що витікають $з$ нових завдань і зовнішніх умов функціонування і розвитку ІКТ-систем;

- не задовольняються обмеження на ресурсне (кадрове i/aбо матеріальнотехнічне, i/або фінансове) забезпечення функціонування і розвитку ІКТ-систем, що зумовлює необхідність зменшення певних витрат, приведення їх у відповідність до передбачених або припустимих, за одночасного зниження ризиків функціонування i розвитку ІКТ-системи. Це стосується як витрат і ризиків із забезпечення поточного функціонування ІКТ-системи, так і витрат і ризиків, що пов’язані з ії інноваційним розвитком. Оскільки екстенсивне нарощування масштабів ІКТ-систем у сучасних умовах стає все більш і більш ресурсно обтяжливим, технологічно не обгрунтованим, а тому в цілому неприпустимим шляхом розвитку ІКТ-систем, стратегія ресурсного забезпечення інформатизації ООС має спиратися як на останні досягнення в IКТ- 
сфері, так і передбачати збалансоване поєднання бізнес-вимог до ІКТ-систем і обсягів ресурсного забезпечення на їх задоволення, що реально виділяються. Водночас, під час проектування і реалізації цієї стратегї мають бути враховані вимоги щодо доцільних строків упровадження інноваційних IКТ-рішень, а також забезпечення можливо меншої вартості володіння ІКТ-системою для ООС.

Зазначимо також, що найближчим часом корпоративним IКТ-системам буде все складніше конкурувати з ринковими ІКТ-аутсорсерами. Тому дуже важливо, аби ООС почали більш економічно обгрунтовано ставитися до використання IКТ, знаходити підходи ощадливого задоволення власних ІКТ-потреб. Це задоволення повинно мати для кожного ООС конкретну вартість. I нарешті, стандартизація і калькуляція витрат на забезпечення внутрішніх ІКТ-процесів в ООС дасть змогу провести оцінку економічної доцільності впровадження тих чи інших ІКТ-інновацій, наприклад. здійснити перехід на певні зовнішні ІКТ-сервіси на умовах аутсорсингу. Інакше, економічно не обгрунтований аутсорсинг, або така ж не обгрунтована повна відмова від нього можуть викликати непередбачені наслідки, як для ООС, так і для керівників ІКТ-підрозділів, спричинити підвищення ризиків функціонування i розвитку ІКТ-системи.

Сучасна ІКТ-практика вказує на те, що продуктивним підходом розв’язання ІКТ-проблем є перехід від виключно корпоративної до повністю аутсорсингової або гібридної сервісної моделі управління ІКТ. Вибір тої чи іншої моделі має бути різнобічно обгрунтованим у кожному конкретному разі (для певного ООС, того, чи іншого ІКТ-рішення, часу і місця його впровадження і т. ін.) виходячи з ІКТ-потреб і ресурсних можливостей ООС і з урахуванням стану ринку ІКТ-продуктів і сервісів. Такий підхід спрямований на комплексне розв'язання в ООС ІКТ-проблем, інтегроване врахування всіх трьох із зазначених вище. Якщо за допомогою цього підходу не вдається повністю розв'язати ці проблеми зразу, усе ж слід очікувати, що його обгрунтоване застосування дозволить суттєво пом'якшити негативний вплив кожної із зазначених проблем на загальну ефективність реалізації ІКТ-процесів.

По-четверте, те, що стосується зміни функцій ІКТ-підрозділу, відповідного розподілу всього необхідного спектру ІКТ-функцій з підтримання бізнес-процесів, між ІКТ-підрозділом і бізнес-підрозділами ООС. 
Зауважимо, що далі будуть розглянуті функції ІКТ-підрозділів, що підтримують і розвивають ІКТ-системи на базі адаптивних IКМ, тобто тих, які у своїй роботі спираються на хмарну (корпоративну або загальнодоступну) ІКТінфраструктуру.

Склад ІКТ-функцій і характер їх розподілу (перерозподілу) залежать від того, яка модель буде обрана ООС для забезпечення необхідних йому ІКТ-сервісів (сервісна модель) - модель на базі використання корпоративної чи загальнодоступної хмари або комбінація цих моделей. Тобто, якщо стратегія розвитку інформатизації ООС передбачає використання хмарних технологій (XТ), можливі такі сервісні моделі реалізації хмарного підходу:

- створення і підтримання власної корпоративної хмари (КХ), що обов’язково включає побудову, підтримання функціонування і забезпечення розвитку власного центру опрацювання даних (ЦОД), його програмно-апаратних засобів й електронних інформаційних ресурсів, а також передбачає існування в структурі ООС потужного ІКТ-підрозділу;

- орієнтація на загальнодоступну хмару (3X), що передбачає використання на умовах повного аутсорсингу засобів і сервісів зовнішньої відносно ООС розподіленої мережі ЦОД, а також наявність у структурі ООС ІКТ-підрозділу. Функції цього ІКТпідрозділу суттєво відрізняються від тих, які виконує (має виконувати) ІКТ-підрозділ, що спирається на корпоративну сервісну модель, а чисельність ІКТ-персоналу i вимоги до їхньої кваліфікації є порівняльно меншими, ніж у разі використання КХ;

- орієнтація на гібридну (комбіновану) модель реалізації ІКТ-сервісів (одночасне використання як КХ, так і 3X).

У кожної з перелічених моделей є свої позитивні і негативні риси, що з часом змінюються (наприклад, з одного боку, змінюються властивості ІКМ, а, з іншого: ІКТ-потреби користувачів, рівень „озброєності” ІКТ-підрозділів, професійний потенціал його персоналу, бізнес-пріоритети і фінансові можливості ООС). Для зменшення ймовірності появи значних проблем i, як наслідок, додаткових непередбачених i невиправданих витрат на розвиток ІКТ-систем ООС, під час проектування стратегії їхнього розвитку, обирання конкретної сервісної моделі задоволення наявних і перспективних ІКТ-потреб відповідним працівникам ООС слід 
ретельно проаналізувати доцільність використання всіх трьох зазначених моделей для кожного класу необхідних ІКТ-сервісів.

3 часом ІКТ-тактика реалізації обраної ІКТ-стратегії має переглядатися, надаючи на тому чи іншому етапі своєї реалізації перевагу тій, або іншій сервісній моделі, пропонуючи різні різнобічно обгрунтовані співвідношення застосувань тих чи інших варіантів реалізації ІКТ-систем.

3 урахуванням аналізу досвіду використання хмарного підходу, що наведений, зокрема, у [4], можна зробити висновок про те, що під час обгрунтування вибору варіанту сервісної моделі для ООС, мають розглядатися всі три можливі моделі хмарних рішень, залежно від:

1. Обраних ООС пріоритетів власного функціонування і розвитку (наприклад, забезпечення рівного доступу до якісної освіти, конкурентоспроможності на ринку освітніх послуг, отримання максимального прибутку, мінімізація витрат, соціальноекономічна ефективність).

2. Результатів розрахунків та аналізу обсягів витрат на забезпечення ключових характеристик IКТ-систем, ІКТ-сервісів, що вони надають щодо:

- безпеки даних і мережних комунікацій;

• надійності надання передбачених сервісів;

• оперативного підтримання функціонування і розвитку ІКТ-системи;

- налаштування наявних стандартних засобів віртуалізації i хмарних інструментів для використання у наявному в ООС IКТ-середовищі, а також забезпечення гнучкості ІКТ-системи під час ii переналаштовування i розвитку (наприклад, модернізації, пов'язаної з оновленням, осучасненням складу програмноапаратних засобів або нарощенні продуктивності у зв’язку зі змінами масштабу i/чи функцій ІКТ-процесів);

- формування (у тому числі, у певному часовому розрізі) якісного кадрового складу персоналу власного IКТ-підрозділу (його навчання, перенавчання, підвищення кваліфікації і сертифікація).

3. Наявності на ІКТ-ринку необхідного i досконалого програмного забезпечення. 
4. Наявності на ІКТ-ринку відповідних надійних, достатньо досвідчених ІКТаутсорсерів, здатних до довготривалої інтегрованої гармонійної співпраці за прийнятну ціну.

У процесі вибору варіантів слід також враховувати, що:

- використання КХ доцільно для тих освітніх систем, ООС, що більш вимогливо ставляться до питань безпеки даних і виконання правил регулюючих органів;

- під час вибору як кількості, так і конкретних ІКТ-аутсорсерів хмарних сервісів (ХC) слід враховувати, що вибір одного єдиного ІКТ-аутсорсера передбачає його певну монополію, тим самим ставить ООС у певну залежність від нього, „запирає” ООС у межах хмарного стека певного постачальника ХC;

- слід уникати послуг тих ІКТ-аутсорсерів, чиї хмарні стеки добре працюють лише з їх власними компонентами;

- під час використання КX мають бути: стандартизовані процедури 3 розвертання, конфігурації та управління віртуальними машинами, процеси розвертання й управління віртуальними машинами переведені на автоматизовані інструменти, кінцевим користувачам надані засоби самообслуговування, інші підрозділи ООС мають бути готовими до використання єдиної ІКТ-інфраструктури;

- дотепер на ІКТ-ринку відсутні цілісні і функціонально повні ІКТ-рішення для створення і підтримання функціонування КХ (відсутній необхідний і достатній склад ІКТ-рішень, що забезпечують віртуалізацію серверів, систем накопичення i зберігання даних, мереж, а також організації ресурсів i координації їх взаємофункціонування під час реалізації інтегрованого процесу виконання хмарних сервісів). Такі рішення мають бути дібрані з доступних частин ІКТ-продуктів різних виробників, інтегровані як між собою, так і з інтерфейсами користувачів;

• працівники власного ІКТ-підрозділу, що використовує КХ, повинні постійно підтримувати придбані, самостворені i комбіновані компоненти хмарних інструментів, удосконалювати їх функції, покращувати характеристики;

- слід передбачити навчання персоналу ІКТ-підрозділів, що використовує КХ, передусім 3 техніко-технологічних питань реалізації хмарних технологій (XT), зокрема, питань серверної віртуалізації, узгодженості процедур із розгортання i використання віртуальних машин, опанування навичками управління не одиночними 
віртуальними машинами чи робочими навантаженнями, а всім віртуальним ресурсним пулом (для підвищення внутрішньої мотивації персоналу до навчання доцільно обгрунтовувати його необхідність не тільки потребою їх неперервного професійного зростання, але й необхідністю підвищення ефективності діяльності всього ІКТ-підрозділу з точки зору розв’язання загальних і конкретних проблем ООС і СО в цілому);

• використання ПЗ з відкритим кодом дещо знижує рівень залежності від ІКТаутсорсерів;

- слід по-новому оцінити наявні засоби безпеки даних, їх достатність для забезпечення необхідного рівня безпеки даних у КХ. Наявні брандмауери не завжди можуть забезпечити задовільний рівень безпеки у хмарному середовищі, де робочі навантаження можуть бути переміщені в більш безпечне місце. Типово виникає питання оновлення парку брандмауерів із сучасними характеристиками, їх віртуалізації і передавання управління їх роботою програмам автоматизованої координації (оркестрування) хмарною інфраструктурою (XI);

- використання препропріарного програмного забезпечення (програмного забезпечення, що інстальоване і ліцензоване на фізичному процесорі) може викликати проблеми ліцензування у разі міграції віртуальної машини з одного хоста на інший.

Ідеально, коли якість надання КХ хмарних сервісів, зберігаючи принципово важливі для користувачів ООС переваги, буде наближатися до якості, що надають 3Х: наприклад, масштабованість, час i спектр надання сервісу, витрати і проблеми функціонування власного ІКТ-підрозділу, зберігаючи при цьому принципово важливі для користувачів переваги КX, наприклад такі, як підвищена безпека даних i керованість ІКТ-архітектури. Тобто, еластичність надання ХС за замовленням буде такою самою, як у 3Х, а виконання ХC буде здійснюватися в межах брандмауера IКТсистеми.

Проте є деякі принципові відмінності функціонування і розвитку ІКТ-систем залежно від обраної сервісної моделі, що мають бути враховані під час визначення ІКТ-функцій і їх розподілі між підрозділами ООС.

Дуже важливою властивістю КХ є логічне відокремлення ІКТ-додатків від загальносистемних програмно-апаратних засобів ІКТ-систем. Якщо за традиційною моделлю організації роботи ІКТ-систем виконання тих чи інших конкретних IКТ- 
додатків чітко закріплюють за певними серверами, то у КХ попередньо невідомо, які сервери будуть працювати 3 яким додатками. Тобто, ІКТ-додатки будуть виконуватися на тих серверах, що мають вільні обчислювальні ресурси у той момент часу, коли ці додатки необхідно запустити. Ці особливості відображаються як у специфіці організації спільного функціонування складових інфраструктури ІКТсистем, так і у змісті діяльності ІКТ-персоналу.

Ще один важливий фактор, який слід враховувати під час переходу до організації діяльності ІКТ-підрозділу за моделлю КХ, полягає в тому, що в ООС практично неможливо миттєво і повністю відмовитися від наявного парку ІКТ-засобів (передусім, персональних комп’ютерів, якими оснащені різні підрозділи, а також численних успадкованих програмних додатків, певна частина яких уже багато часу успішно використовується користувачами, „влаштовує” їх), чи дуже швидко його оновити під вимоги власної КХ. Утім переважна більшість ІКТ-додатків „прив’ язані” до певних платформ. Тому, щоб надати користувачам можливість використовувати наявні ІКТ-додатки ще певний час, у разі переходу до КХ платформи ці ІКТ-додатки мають бути переналаштовані під хмарні вимоги.

Під час переходу від традиційної ІКТ-системи до КХ-орієнтованої (реалізації проекту розвитку ІКТ-систем у переході до використання адаптивних IКМ), виникає так звана точка біфуркації (за термінологією проектного підходу [5]) на кривій еволюції функціонально-процесуальних користувальних властивостей IКМ, що проявляється як проблемна ситуація у їх розвитку.

Ця точка біфуркації відображає протиріччя між визначальними властивостями XC й інфраструктурою наявної ІКТ-системи, а також характером організації діяльності ІКТ-підрозділів, розподілом відповідальності за виконання окремих частин єдиного процесу реалізації ІКТ-сервісів: розподілом відповідальності між ІКТпідрозділом і користувачами ІКТ-додатків. За хмарним підходом ІКТ-підрозділ відповідає за якісне за замовленням і без втручання користувача надання йому ХС (за безперебійне функціонування й адекватний розвиток IКТ-архітектури, наявність достатніх i доступних користувачеві IКТ-ресурсів, налаштування IКТінфраструктури), а користувач - за вибір конкретної реалізації власних ІКТ-додатків, налаштування й управління ними, а також за контроль їх працездатності. Тобто за 
хмарною моделлю ІКТ-підрозділ не відповідає за функціонування і розвиток ІКТдодатків користувачів.

Оскільки точка біфуркації за означенням - це проблемна ситуація (біфуркаціийна проблема), для іiі розв’язання потрібні певний час і ресурси (кадрові, науково-технічні, фінансові, організаційні, матеріально-технічні, енергетичні).

Точка переходу є граничною точкою простору біфуркаційної проблеми, яка фіксує момент іï розв’язання, тобто момент, коли у власника ІКТ-системи 3'являються достатні інструменти управління, що опрацьовують всі три типи ресурсів: сервери, системи зберігання даних і мережі, як загальний ресурсний пул, що може бути наданий користувачеві за його запитом.

За даними компанії New River Marketing Research [4, с. 60], до проблем КХ можна віднести такі:

• бюджет. КХ можуть бути коштовними. Тому слід вияснити можливі верхню і нижню межі повернення інвестицій;

- інтеграція із 3Х. Слід будувати КХ так, щоб з часом мати можливість перейти до використання гібридної хмарної моделі, якщо у перспективі знадобляться деякі додаткові ІКТ-сервіси 3X, або виникнуть певні переваги їхнього часткового використання. Для цього слід переконатися в безпеці і верифікації ІКТ-систем, щоб можна було управляти робочими навантаженнями в обох типах хмар;

- масштаб. У КХ, типово, немає тої масштабованості, яку надають великі аутсорсери $3 \mathrm{X}$;

- неперервна переконфігурація. Скоріш усього, необхідно буде демонтувати сервери та деякі інші складові ІКТ-інфраструктури і перемісти їх до IКТінфраструктури КХ, у той час, коли вони ще використовуються в існуючій IКТсистемі. Це може створити величезні проблеми для всієї ООС;

- застаріле обладнання. Від дуже застарілих серверів необхідно відмовитися. Не слід намагатися повторно використовувати сервери, що вимагають ручної конфігурації у КХ, оскільки їх неможливо „долучити” до систем автоматизації i застосувати програмне забезпечення для автоматизованої координації ІКТінфраструктури;

- застарілі технології. Для будь-якої ІКТ-організації, особливо малої, складність і швидкість зміни технологій призводять до ускладнення іiі використання. 
Як тільки інвестиції спрямовані на створення КХ, щоб їх ефективно використати, необхідно постійно підтримувати оновлення компонентів загальносистемного програмного забезпечення;

- побоювання (страх) перемін. Персонал ІКТ-підрозділу, можливо, повністю не знайомий, або недостатньо знайомий 3 КХ. Тому виникнуть додаткові витрати, пов'язані з їхнім навчанням. Ймовірно необхідно буде створювати нові операційні процеси й переробляти існуючі.

Наведемо спостереження деяких авторитетних в галузі ІКТ-аналітики компаній щодо певних особливостей роботи персоналу в сучасному „ІКТ-ландшафті” організації, які слід враховувати при розвитку інформатизації ООС.

Так, дослідження компанії Check Point вказують на те, що зростання масштабів компаній, використання ІКТ-засобів практично стовідсотковим складом працівників, зростання кількості працівників, які працюють дистанційно (віддалено), призводить до ускладнення інфраструктури безпеки ІКТ-систем і розширення задач системних адміністраторів із захисту мобільних даних $\mathrm{i}$ бездротових мереж, а також адміністрування користувачів [4, с. 74].. Дослідження Cisco Connected Word Report, проведене аналітичною компанією InsightExpress, виявило значну невідповідність поведінки працівників компаній корпоративним правилам в галузі IKT i, особливо у тому, що стосується їхнього бажання працювати у мобільному режимі за допомогою численних різнотипних пристроїв, соціальних мереж i нових форм комунікацій, включаючи відео. У цілому дослідження виявило необхідність оновлення ІКТ-правил і політик, їх узгодження з бажанням працівників отримати більше прав і мати доступ до корпоративних i побутових даних з будь-якого місця у будь-який час за допомогою всіх можливих пристроїв [4, с. 72]. С'юзен Кремм з компанії Valuedance вважає, що роль ІКТ-підрозділу постійно зміщується в бік ІКТ-підтримки. Це надає змогу бізнес-підрозділам бути більш самостійними у забезпеченні ІКТ-навчання своїх працівників, проведенні відповідних тренінгів і наданні необхідних навчальних інструментів 3 урахуванням корпоративних ІКТ-правил i вимог (наприклад, забезпечення точних і безпечних даних, інтеграція бізнес-процесів і розширення внутрішньо корпоративного співробітництва) [6, с. 46]. Окрім цього, для поліпшення якості обслуговування - гнучкості, зручності і швидкості надання ХC за ІКТзапитами користувачів, компанії-провайдери ХС створюють і підтримують так звані 
портали самообслуговування. Так, $80 \%$ послуг дата-центру корпорації Suncorp Group, Австралія забезпечується через портал самообслуговування.

Підкреслимо, що на склад функцій ІКТ-підрозділу, на обсяг робіт, що виконують його працівники, визначально впливає відношення ООС до аутсорсингу. Необхідність звернення ООС до послуг компаній-аутсорсерів пов'язано, передусім, 3 тим, що забезпечити ефективність ІКТ-процесів, якість надання ІКТ-послуг, розв’язати кадрові питання за вкрай обмежених обсягів виділених фінансових ресурсів - завдання, які виконати ООС самотужки дуже складно, а іноді, практично неможливо. Тому керівники ООС, які відповідають за виконання завдань інформатизації ООС, мають дати відповідь на запитання: чи передбачається залучити до виконання ІКТ-функцій, робіт із підтримання і розвитку власних ІКТ-систем компанії-аутсорсери? Якщо так, то яка частина, які конкретно роботи будуть передані? Як будуть побудовані взаємовідносини між ІКТ-підрозділом ООС i компаніями-аутсорсерами (однією чи кількома).

Як було вище зазначено, ІКТ-аутсорсинг доцільний для тих структур, які намагаються забезпечити високу конкурентоспроможність на профільному для них ринку товарів і послуг, проте виробництво ІКТ-послуг не є для них основним видом діяльності. Дуже важливо при цьому, аби ІКТ-аутсорсинг був органічно вбудованим у загальну організаційно-функціональну будову ІКТ-сфери, зокрема, у процеси інформатизації освіти. Тобто, слід забезпечити раціональне поєднання, інтеграцію зусиль ООС (користувачів ІКТ-послуг) і компаній-аутсорсерів (їх постачальників) щодо підвищення ефективності процесу інформатизації основних видів діяльності OOC: навчальної, наукової та управлінської, вимоги до рівня інформаційного забезпечення яких неперервно зростають.

Необхідність оптимізації витрат на ІКТ і забезпечення оперативної підтримки бізнесу в умовах обмеження ресурсів на розвиток власних ІКТ-систем стала причиною зростання інтересу до ІКТ-аутсорсингу в Україні. Цікавим з точки зору можливості використання в СО видається досвід української компанії „Міратех”, що пропонує новий в Україні підхід до довгострокового співробітництва, нову його форму - створення виділеного центру ІКТ-компетенцій (IT Competence Center, далі - Центр) [7]. Сенс такого підходу полягає в тому, що постачальник ІКТ-послуг 3 урахуванням потреб компанії-клієнта формує в структурі компанії-аутсорсера (у 
даному разі, компанії „Міратех”) команду ІКТ-фахівців 3 різних необхідних спеціальностей, а також створює необхідну інфраструктуру для забезпечення іï діяльності. Сформована команда концентрується виключно на виконанні ІКТпроектів компанії-клієнта. Тобто за цим підходом компанія-клієнт на довгостроковій основі залучає для виконання необхідних їй проектів, робіт зовнішню команду висококваліфікованих фахівців із власною інфраструктурою. Утім працівники Центру і ІКТ-підрозділу компанії-клієнта працюють спільно і злагоджено, об'єднуючись на довгостроковій основі в єдину проектну команду, доповнюючи одні інших, забезпечуючи спільний кінцевий результат. Нині Центр пропонує певний спектр ІКТпослуг: розробка нових ІКТ-рішень і підтримка інформаційних систем, міграція на інші ІКТ-платформи, тестування ІКТ-систем, підтримка програмного забезпечення та iн.

Зниження головного ризику для компанії-клієнта - залежності від компаніїаутсорсера, від якості і надійності надання Центром замовлених ІКТ-послуг, забезпечується через механізми детального регулювання взаємовідносинами, що передбачаються відповідним договором між компанією-клієнтом і Центром (наприклад, зобов'язання із заміни і з надання додаткових ресурсів, час реакції на запит і його опрацювання, метрики якості роботи та ін.). Одним 3 інструментів, що використовується для оперативного моніторингу виконання робіт, є, так звана, система метрик. Такими метриками можуть бути, наприклад, ефективність виконання замовлень (строки, трудомісткість і вартість робіт наближені до тих, що очікував клієнт), якість надання послуг (продуктивність, акуратність та ін.), плинність кадрів, характеристики завантажених ресурсів, звітність про надання сервісів та ін. На основі визначеної системи метрик, зокрема, здійснюється моніторинг різних виявлених дефектів у створеному і впровадженому в ІКТ-системі компанії-клієнта програмному забезпечені, а також якості роботи залучених працівників (недоопрацювання на стадії бізнес-аналізу, розробки, тестування та ін.), що допомагає оперативно вживати заходів з виправлення ситуації, що виникла. Окрім того, на основі показників такого моніторингу, відстежуються: час, що витрачений аналітиками, розробниками i тестувальниками конкретних ІКТ-задач; розподіл витрат у різні моменти і за різні періоди часу в межах окремих проектів ІКТ-систем [8]. Одним із важливих чинників зниження ризику залежності клієнта від постачальника ІКТ-послуг, $є$ наявність 
ефективного каналу комунікацій між ними. Поряд 3 такою його традиційною i відомою формою реалізації як проведенням регулярних безпосередніх зустрічей членів спільної проектної команди, доцільно оснастити відповідні підрозділи клієнта і постачальника ІКТ-послуг аудіо і відео засобами, що забезпечують дистанційну взаємодію членів віртуальної проектної команди, у тому числі забезпечити їх необхідними індивідуальними мобільними засобами електронних комунікацій, МІП. Обов’язковою умовою забезпечення успішної спільної діяльності компанії-клієнта i Центра є функціонування у структурі компанії-аутсорсера системи управління якістю надання сервісів. Наведений досвід має бути проаналізований i, там де це виявиться доцільним, в інформатизації СО впроваджений.

Аналізуючи складові наведеного вище інноваційного причинно-наслідкового ланцюга, що висвітлює i деталізує загальну проблему - невідповідність організаційно-функціональної моделі реалізації в ООС ІКТ-процесів, зокрема, структури ІКТ-підрозділів об' єктивним умовам сучасного стану розвитку ІКМ і ринку IКТ-послуг, зробимо такий узагальнюючий висновок — для переважної більшості ООС найбільи дочільною сервісною моделлю можна визнати модель на базі $3 X$ з повним аутсорсингом. Проте, це не виключає наявності в ООС невеликого за чисельністю ІКТ-підрозділу, або окремих працівників, які відповідають за стан і розвиток інформатизації в ООС і співпрацюють з компанією-аутсорсером.

У свою чергу, для великих університетів і профільних наукових установ найбільш доцільною слід вважати гібридну сервісну модель, оскільки профіль підготовки фахівців і тематика наукової діяльності цих ООС передбачає наявність в їхніх структурах як висококваліфікованих спеціалістів у галузі ІКТ і розвинених IКТпідрозділів, так і власної потужної ІКТ-інфраструктури, що забезпечують підтримку основних видів діяльності ООС.

Те, що стосується нових освітніх завдань підготовки кадрового корпусу фахівців для ІКТ-сфери, розв’язання яких закладає освітню основу професійного зростання IКТ-персоналу, у тому числі персоналу ІКТ-підрозділів ООС на сучасному етапі інформатизації CO, впливає на склад їх функцій, на загальну ефективність функціонування і розвитку ІКТ-систем ООС.

Не торкаючись загальних питань організації освіти на сучасному етапі розвитку суспільства, що не $є$ предметом даного розгляду, зазначимо лише ті аспекти 
формування педагогічних систем із підготовки фахівців для IКТ-сфери, що мають визначальний вплив на якісні показники навчання, забезпечують їхню відповідність сучасному стану розвитку ІКТ-сфери, зокрема, впливають на ефективність процесу інформатизації СО, результативність впровадження іiї засобів і технологій у широку освітню практику.

Безумовно до таких аспектів слід віднести зміст інформатичної освіти. 3 метою визначення цього змісту на рівні сучасних світових вимог, неперервного його осучаснення відповідно до потреб ІКТ-практики доцільно використати закордонний досвід поширення через відповідні публікації так званих „кращих практик”, зокрема, використати напрацювання, що подані у ITIL (IT Infrastructure Library) - бібліотеці, де узагальнено кращий досвід організації роботи підрозділів і компаній, що надають ІКТ-послуги [9].

У шести книгах, що входять нині до складу третьої версії цієї бібліотеки (ITIL, v3, книга 1: Service Strategy - Стратегія сервісу; книга 2: Service Design Проектування сервісу; книга 3: Service Transition - Перетворення сервісу; книга 4: Service Operation - Експлуатація сервісу; книга 5: Continual Service Improvement Постійне покращення сервісу і книга 6: Introduction to ITIL Service Management Practices - Вступ до практики управління сервісами), докладно подані найбільш важливі види діяльності у роботі ІКТ-структур, перелік сфер відповідальності їх суб’ єктів, задач і процедур, що можуть бути адаптованими у будь-якій організації, яка користується послугами IКТ-аутсорсингу або власного IКТ-підрозділу.

До ключових переваг ITIL слід віднести:

- використання кращих знань і перевірених практик;

- оріснтація діяльності ІКТ-систем на розв'язання основних завдань функціонування і розвитку організації;

• визнання IКТ-підрозділів як постачальників ІКТ-послуг для інших підрозділів організації;

- регламентування функціонування ІКТ-підрозділів угодою про рівень якості сервісу (SLA - Service Level Agreement);

- визначення стандартів і правил діяльності для IКТ-персоналу;

• націленість на забезпечення максимально можливої для користувачів якості надання ІКТ-послуг; 
• впровадження в управління ІКТ-сервісами методології управління якістю (Total Quality Management);

• можливість підтвердження і пояснення вартості ІКТ-сервісів відповідно до якості їх надання.

У цілому, застосування ITIL-підходу робить акцент на необхідності неперервних змін й удосконалення якості надання IКТ-сервісів, як з точки зору організації, так і з точки зору користувача. Користувачеві надається у використання не сама ІКТ-система, а певний спектр автоматизованих функцій, що допомагають йому в роботі. У свою чергу, ІКТ-підрозділ має забезпечити виконання всіх запитаних користувачем функцій, відповідне налаштування і підтримання програмно-апаратних засобів, мережі та предметних додатків.

3 іншого боку, використання ITIL-підходу сприяє підвищенню ефективності функціонування i розвитку ІКТ-систем ООС. Так, наприклад, за допомогою інструментів ITIL-підходу з'являється можливість обгрунтування для керівництва ООС необхідності інвестицій в ІКТ-системи, раціоналізації роботи ІКТ-підрозділу (зокрема, вирішити проблеми відношень у середині ІКТ-підрозділу і вибудувати ефективні комунікації), скоротити кількість збоїв ІКТ-інфраструктури і підвищити задоволеність користувачів, що часто є самим болісним моментом).

У загальному плані, застосування ITIL-підходу дозволяє IKT-підрозділам COO: підвищити показники економічної ефективності ІКТ-сервісів, стандартизувати корпоративні і міжкорпоративні взаємозв'язки, підвищити прозорість свого функціонування, раціоналізувати роботу, спрямувати ії на загальнокорпоративні цілі. Як результат, це призводить до консолідації наявних ресурсів освітньої діяльності, оптимізації витрат на формування, підтримання і розвиток власних ІКТ-систем, у цілому — підвищення конкурентоспроможності ООС і СО.

Бібліотека кращих практик освітніх ІКТ-застосувань (БОІТ - бібліотека освітніх IKT), з використанням досвіду, що поданий у бібліотеці ITIL, має бути започаткована і регулярно видаватися. У ній повинен висвітлюватися не тільки вже набутий досвід успішного впровадження ІКТ-систем в різні підсистеми освіти, але й наводитися результати завершених наукових досліджень і захищених дисертаційних робіт з усього спектру ІКТ-продуктів, що існують на ІКТ-ринку і використовуються 
(можуть використовуватися) для забезпечення навчальної, управлінської та наукової діяльності, яка здійснюється в СО.

Врахування досвіду кращих ІКТ-практик у галузі освіти, що висвітлюватимуться в БОІТ, дозволить не тільки підвищити ефективність їх широкого впровадження, але й дозволить сформувати вимоги до професійної підготовки і перепідготовки ІКТ-фахівців, зокрема, змісту освіти і педагогічних технологій, характеристик складу і структури навчального середовища, параметрів професійних компетентностей, що формуються у відповідних педагогічних системах.

Висновки. Отже, розглянуто всі виокремленні вище складові інноваційного причинно-наслідкового ланцюга, що висвітлює і деталізує загальну проблему невідповідність організаційно-функціональної структури ІТ-підрозділів ООС об'єктивним умовам сучасного стану розвитку засобів і технологій інформаційного суспільства.

Насамкінець можна впевнено стверджувати, що головні концептуальні засади стратегії подальшої масштабної інформатизації освіти і науки України мають базуватися на концепції ХО із суттєвим поглибленням інтеграції галузевих зусиль у цьому напрямі і можливостей ІКТ-бізнесу на основі застосування механізмів аутсорсингу. Попри це як поточні i перспективні інвестиції у розвиток ІКТінфраструктури, так і всі наявні ІКТ-системи й окремі ІКТ-рішення, що спрямовані на інформатизацію СО на всіх їі організаційних рівнях, мають бути проаналізовані й відкоректовані з точки зору можливості застосування технологій ХО як альтернативи.

\section{Список використаних джерел}

1. Патру M. Глобализация школьного образования. Роль ИКТ и международного сотрудничества в обеспечении доступности и качества общего образования / М. Патру // Информатика и образование. — 2010. — № 2. - С. $103-$ 107.

2. Кремень В. Г. Людина перед викликом цивілізації: творчість, людина, освіта / В. Г. Кремень // Феномен інновацій: освіта, суспільство, культура / за ред. В. Г. Кременя. - К. : Педагогічна думка, 2008. - С. 9-48.

3. Биков В. Ю. Моделі організаційних систем відкритої освіти : монографія / В. Ю. Биков. - К. : Атіка, 2008. - 684 с. 
4. Жданов Б. По ухабистым дорогам к частным облакам / Б. Жданов // ИТМ. Информационные технологии для менеджмента. - 2011. - № 1-2. - С. 58-62.

5. Азаров Н. Я. Инновационные механизмы управления программами развития / Н. Я. Азаров, Ф. А. Ярошенко, С. Д. Бушуев. - К. : «Саммит-Книга», 2011. - 520 с.

6. Заберите ИТ из ИТ-отдела // ИТМ. Информационные технологии для менеджмента. - 2011. - №7. - С. 45-47.

7. Гольденберг И. Центр ИТ-компетенций позволяет клиенту сосредоточиться на стратегии / И. Гольденберг // ИТМ. Информационные технологии для менеджмента. - 2011. - №6. - С. 54-57.

8. Ефремов H. Команда ИТ-специалистов в аренду - новая модель аутсорсинга / Н. Ефремов // ИТМ. Информационные технологии для менеджмента. 2011. — № 6. - C. 55-56.

9. Библиотека передового ИТ-опыта — ориентир на улучшение ИТ-сервисов и их еффективности // ИТМ. Информационные технологии для менеджмента. — 2011. — № 7. - С. 48-49.

\section{ИКТ-АУТСОРСИНГ И НОВЫЕ ФУНКЦИИ ИКТ-ПОДРАЗДЕЛЕНИЙ УЧЕБНЫХ ЗАВЕДЕНИЙ И НАУЧНЫХ УЧРЕЖДЕНИЙ}

Быков Валерий Ефимович, доктор технических наук, профессор, действительный член НАПН Украины, директор Института информационных технологий и средств обучения НАПН Украины, Киев, valbykov@ gmail.com

\section{Аннотация}

Представлен широкий по направлениям и глубокий по исследованиям анализ современного этапа информатизации общества и образования. С позиций системного подхода рассмотрена инновационная причинно-следственная цепь, освещающая и детализирующая общую проблему - несоответствие организационнофункциональной структуры ИТ-подразделений образовательных и научных учреждений объективным условиям современного состояния развития средств и технологий информационного общества. В связи с актуальностью применения на современном этапе информатизации системы образования механизма аутсорсинга для обеспечения функционирования и развития ИКТ-систем образовательных организационных структур, рассмотрены некоторые теоретико-практические аспекты 
этого понятия и явления. Определены функции ИКТ-подразделений, поддерживающих и развивающих ИКТ-системы на базе адаптивных информационнокоммуникационных сетей, то есть тех, которые в своей работе опираются на облачную (корпоративную или общедоступную) ИКТ-инфраструктуру.

Ключевые слова: информатизация образования, аутсорсинг, образовательные организационные структуры, облачные технологии.

\section{ICT-OUTSOURCING AND NEW FUNCTIONS OF ICT DEPARTMENTS OF EDUCATIONAL AND SCIENTIFIC INSTITUTIONS}

Valeriy Yu. Bykov, Dr. of Technical Sciences, professor, member of NAPS of Ukraine, Director of the Institute of Information Technologies and Learning Tools of the National Academy of Pedagogical Sciences of Ukraine, Kyiv, valbykov@gmail.com

\section{Resume}

In the article the deep analysis of broad areas of research of the current stage of information society technologies in education is provided. From the standpoint of systems approach a causal chain that describes and details the common problem - the lack of organizational and functional structure of IT departments of educational and scientific institutions in view of the objective conditions of the current state of development of information technologies is considered. Due to urgency of application of the outsourcing mechanism for the operation and development of the ICT systems of educational organizational structures at the present stage of informatization of education, some theoretical and practical aspects of this concept and phenomenon are revealed. The functions of ICT departments that support and develop ICT systems based on adaptive information and communication networks, i.e. those based on cloud (corporate or public) ICT infrastructure, are described.

Keywords: informatization of education, outsourcing, educational organizational structures, cloud technologies.

Матеріал надійшов до редакції 20.09.2012 p 